\title{
Water quality and ecology of the River Lee: mass balance and a review of temporal and spatial data
}

\author{
Deborah L. Snook and Paul G. Whitehead \\ Aquatic Environment Research Centre, University of Reading, Whiteknights, Reading RG6 6AB, UK \\ Email for corresponding author: p.g.whitehead@reading.ac.uk
}

\begin{abstract}
A regional overview of the water quality and ecology of the River Lee catchment is presented. Specifically, data describing the chemical, microbiological and macrobiological water quality and fisheries communities have been analysed, based on a division into river, sewage treatment works, fish-farm, lake and industrial samples. Nutrient enrichment and the highest concentrations of metals and micro-organics were found in the urbanised, lower reaches of the Lee and in the Lee Navigation. Average annual concentrations of metals were generally within environmental quality standards although, on many occasions, concentrations of cadmium, copper, lead, mercury and zinc were in excess of the standards. Various organic substances (used as herbicides, fungicides, insecticides, chlorination by-products and industrial solvents) were widely detected in the Lee system. Concentrations of ten micro-organic substances were observed in excess of their environmental quality standards, though not in terms of annual averages. Sewage treatment works were the principal point source input of nutrients, metals and micro-organic determinands to the catchment. Diffuse nitrogen sources contributed approximately $60 \%$ and $27 \%$ of the in-stream load in the upper and lower Lee respectively, whereas approximately $60 \%$ and $20 \%$ of the in-stream phosphorus load was derived from diffuse sources in the upper and lower Lee. For metals, the most significant source was the urban runoff from North London. In reaches less affected by effluent discharges, diffuse runoff from urban and agricultural areas dominated trends. High microbiological content, observed in the River Lee particularly in urbanised reaches, was far in excess of the EC Bathing Water Directive standards. Water quality issues and degraded habitat in the lower reaches of the Lee have led to impoverished aquatic fauna but, within the mid-catchment reaches and upper agricultural tributaries, less nutrient enrichment and channel alteration has permitted more diverse aquatic fauna.
\end{abstract}

Keywords: River Lee, River Thames, water quality, nutrients, metals, ecology, hydrology, diffuse and point source pollution

\section{Introduction}

Large $\left(1000 \mathrm{~km}^{2}\right)$ river systems are often key resources providing water for drinking supply, industry and agriculture. In addition, such large systems may include areas important for recreation and conservation. In many cases, diffuse and point source pollution threaten the water quality and ecological status and the pollution may affect the downstream utilisation of the river water. Quantifying the impacts of water pollution is particularly important for large river systems in the south-east of England, which has a high population density, major industrial infrastructure and agricultural areas often under intensive arable production. Present climate-change predictions suggest that the summer flows in the south-east of England are likely to decrease, further reducing the capacity for dilution of pollution and requiring major new developments such as large scale reservoirs or water transfer schemes. Thus, it is increasingly important to understand the behaviour of large river systems, especially those affected by both diffuse and urban pollution.

The Land Ocean Interaction Study (LOIS) was a major UK research initiative to quantify the relative effect of diffuse and point source pollution for a broad range of determinands including nutrients and metals on the rivers draining into the Humber estuary and, subsequently, to the North Sea (Neal, 1997, 1998; Neal and Robson, 2000). Other studies in which diffuse and point source pollution have been investigated include the Large Scale Processes and Lowland Catchment Research projects (Langan et al., 1997; Neal et al., 1997, 2004). Whitehead et al. (1979, 1981) studied and modelled the Bedford Ouse catchment (area $8450 \mathrm{~km}^{2}$ ) to assess the effects of diffuse and urban pollution. Yet, there are still 
relatively few studies of the water quality and ecological status of large, heavily urbanised catchments in the UK. The River Aire in northern England, which drains a predominately urban catchment, was part of the LOIS programme, though the flow regime of the Aire is unlikely to be affected by climate change to the same extent as the rivers in the south-east of England.

For the River Lee, a regionally important, large river system in the south-east of England, this study investigates point and diffuse sources of pollution and the ecological response, using a database of flow, water quality and ecology collated between 1990 and 2001 by the Environment Agency and British Waterways, linked to a comprehensive study of the Lee for London's Waterway Partnership (Snook et al., 2002). Specifically, the factors affecting the spatial and temporal variations in (i) determinands related to eutrophication (nitrogen, phosphorus, BOD, temperature), (ii) metals and (iii) micro-organic pollutants have been studied and spatial variations in water quality have been related to the ecological status.

With legislation such as the Water Framework Directive and new initiatives such as the Olympics Bid and regeneration of the Lee as a recreational area, it is timely to review the water quality and ecology of this system. Also, the work provides an important representation of a major input to the tidal Thames and key typology to set against complementary research on the upper Thames and its tributaries.

\section{Description of the Lee catchment}

The River Lee $\left(1420 \mathrm{~km}^{2}\right)$ rises from springs near Luton, south-east England (National Grid Reference TL 061 248), and flows south through Bedfordshire, Hertfordshire and Greater London before joining the River Thames at Blackwall. The Lee catchment has an average annual rainfall of $637 \mathrm{~mm}$ and a human population of some 2000000 . From its source to its confluence with the Thames, the River Lee is $85 \mathrm{~km}$ long, the last $9 \mathrm{~km}$ being tidal (Environment Agency, 1997). The Lee catchment is principally lowland and the land-use is split along a north-south divide. Agriculture predominates in the north and north-east, principally barley and wheat and the north-western edge of the catchment is within the Chilterns Area of Outstanding Natural Beauty. By contrast, the south is predominantly a mix of suburban and continuous urban development.

The solid geology in the north-west of the catchment is Chalk; for many centuries, this aquifer has been an important source of London's water supply (Flavin and Joseph, 1983; O'Shea and Sage, 1999). To the south-east, this Chalk is overlain by the Tertiary deposits of the London Basin, mainly
London Clay (Geological Survey, 1978; British Geological Survey, 1993). A more detailed description of the geology is given in Snook et al. (2002).

Water abstracted from the River Lee accounts for approximately one-sixth of London's water supply (Reid, 1995). The River Lee is used mainly for abstraction, for discharging treated sewage effluent and for navigation, though recreational activities such as canoeing, sailing and fishing are being promoted within the catchment (Environment Agency, 2001a,b). The Lee valley, its reservoirs and wetlands, are a very important ecological habitat. The Lee catchment encompasses a number of aquatic habitat Sites of Special Scientific Interest (SSSIs) and local Nature Reserves. Downstream of Ware, the Lee Valley Regional Park is a Special Protection Area (SPA) designated for a combination of leisure, recreation and nature conservation.

The flow regime of the Lee has been altered significantly in the Luton and Dunstable areas. Above Hertford treated sewage effluent provides the main flow. The middle and lower reaches of the river Lee, from Hertford to Blackwall, comprise a canalised section with lateral channels for flood relief and water abstraction (including the Lee Navigation and Flood Relief Channel). In the lower Lee catchment there is a complicated system of tributaries, culverts, backwaters and marshes. The River Lee has been navigable for over 900 years and has undergone an array of engineering works during this time (Rust, 1995). In the canalised sections, the river is regulated by impounding lock gates creating very slow flow and extensive deposition of silt over the original gravel bed (Pilcher and Copp, 1997). Urban and industrial areas within the lower catchment have caused an unnatural flow regime with large variations in flow during storm events, creating a potential flood risk over the now densely populated former floodplains (Halcrow Water, 1999). Overabstraction has caused low flows in parts of the catchment such as the Beane and Mimram (Environment Agency, 2001a) and industrial and agricultural practices within the area, both historical and current, have contaminated a number of aquifers in and around urban areas in the upper Lee catchment (Environment Agency, 2001a,b).

The principal direct discharges of sewage effluent into the Lee are from Luton East Hyde, Harpenden, Hatfield Mill Green and Rye Meads Sewage Treatment Works (STWs). Major sewage effluent discharges into the wider catchment are Buntingford STW discharging into the Rib and Deephams STW into the Pymmes Brook (via the Salmon Brook). This latter is the largest single discharge into the catchment.

In summer, low river flows cause the relative proportion of effluent to increase, which affects dilution and so the 
water quality of the watercourse is reduced. Drought conditions accentuate this trend; for example, between 1995 and 1997, reduced precipitation resulted in the length of rivers with 'Good' or 'Very Good' quality (Environment Agency GQA grades) decreasing from 87\% in 1992-1994 to $39 \%$ in 1995-1997 (Environment Agency 2001a). Both the Upper Lee and north London Local Environment Agency Plans (LEAP) express concern over the nutrient status of the catchment; the River Lee and Navigation were designated Eutrophic Sensitive Areas in 1998.

Precipitation following a prolonged dry spell can wash litter, leaves, animal faeces, oil and grit into road drains and into rivers. In extreme cases, this can cause large-scale fishkills as the available oxygen is reduced. To combat this problem, at least in the short term, a hydrogen peroxide oxidation plant has been installed on the Salmon Brook.

The balancing reservoirs at Stansted Airport and Luton Hoo Lakes (run-off from Luton Airport, residential and industrial areas) discharge into the catchment. The Central Electricity Generating Board (CEGB) at West Ham discharges cooling water into the Lee. Two significant fish farms discharge effluent into the Lee catchment: the Gingercress Trout Farm discharges up to $4546 \mathrm{~m}^{3}$ day ${ }^{-1}$ into the Ash, while the Westmill Trout Farm discharges up to $4540 \mathrm{~m}^{3}$ day $^{-1}$ into the Rib.

\section{Methods}

\section{DATA DESCRIPTION}

The water quality and biological data used in this study were principally provided by the Environment Agency, from routine monitoring and one-off surveys between 1991 and 2000 (to provide a 10-year mean) (Table 1). British Waterways provided additional microbiological data for the Lee at Clapton. Measurements of 57 chemical determinands and 10 biological determinands were taken at varying frequency. The chemical determinands described the geological provenance of the surface waters $(\mathrm{pH}$, alkalinity and calcium), the nutrient (nitrogen, phosphorus, silica) and oxygen (BOD, $\mathrm{O}_{2}$ saturation) status, and metal and microorganic pollution. An exhaustive list of both chemical and biological determinands monitored is given in Snook et al. (2002). The biological determinands described (1) the microbiology using total and faecal coliform concentrations, faecal streptococci concentration and the occurrence of salmonella; (2) the macrobiology using biotic indices such as the number of taxa, BMWP-score and ASPT (Average Score per Taxon) devised by the Biological Monitoring Working Party (BMWP) for the 1980 Water Quality Survey of England Wales (Wright et al., 2000); this quantifies the status of the river system; and (3) fish abundance. The

Table 1. Sampling frequency, number of sites and number of determinands used in analyses for chemical, microbiological and macrobiological data.

\begin{tabular}{|c|c|c|c|c|}
\hline $\begin{array}{l}\text { Rivers } \\
\text { (Lee) }\end{array}$ & $\begin{array}{l}\text { Rivers } \\
\text { (tributaries) }\end{array}$ & Sewage & Industrial & Fish farm \\
\hline
\end{tabular}

$\begin{array}{lllllll}\text { CHEMiCAL SAMPLiNG } & & & & & \\ \text { Sampling frequency } & \text { Monthly } & \text { Monthly } & \text { Weekly - annually } & \leq \text { Quarterly } & \leq \text { Monthly } & \leq \text { Monthly } \\ \text { No. of sites } & 19 & 48 & 74 & 3 & 2 & 2 \\ \text { No. determinands } & 67 & 32 & 35 & 18 & 13 & 14\end{array}$

Microbiological SAMPLING

\begin{tabular}{|c|c|c|c|c|c|c|}
\hline Sampling periodicity & Quarterly $^{1}$ & Quarterly $^{1}$ & Intermittently & Not sampled & Not sampled & Not sampled \\
\hline No. of sites & 28 & 23 & 2 & NA & NA & NA \\
\hline No. determinands & 4 & 2 & 2 & NA & NA & NA \\
\hline
\end{tabular}

MACrobiological SAMPLING

Sampling periodicity

No. of sites

Biannual $^{2}$ 24

No. determinands ${ }^{3}$

4

$\begin{array}{ll}\text { Biannual }^{2} & \text { Not sampled } \\ 37 & \text { NA } \\ 2 & \text { NA }\end{array}$

Not sampled
NA

Not sampled

NA

Not sampled

${ }^{1}$ Microbiological sampling was typically undertaken quarterly but this varied at some sites.

${ }^{2}$ Macrobiological sampling was not undertaken each year.

${ }^{3}$ Number of macrobiological determinands refers to indices calculated from survey data.

Fisheries data were from two surveys on the River Lee only.

Where a range is given regarding sampling periodicity this indicates this varied among sites. 
qualitative fisheries abundance data, as the percentage of the total catch represented by each taxon, were available for the tidal lower Lee (1991 survey; Environment Agency, 1992). Combinations of both qualitative and quantitative (biomass and density) fisheries data were available for the River Lee Navigation channel and associated watercourses (1993 survey; Environment Agency, 1994).

\section{ANALYSES}

A graphical and statistical presentation of the 10-year data set has been used to describe the water quality of the Lee catchment in terms of maps of regional concentration, summary statistics and time-series plots.

The regional river network maps give a broad spatial overview for each determinand. Coloured circles represent the 10-year mean determinand concentration for six key sample types: Lee main channel, the tributaries, sewage inputs, fish farms, lakes and industrial sites. In this paper, the main channel and tributary sample types are termed 'river sites'; the remainder are 'non-river sites'. The river sites on the main stem of the Lee and Lee Navigation were divided into 11 sub-catchments based on land-use transition and on major tributary and effluent inputs (Flynn et al., 2002; Fig. 1). Sub-catchment 11 represents the tidal section of the Lee. The river network maps were provided by the Centre of Ecology and Hydrology (CEH) and regional maps were plotted using ArcView GIS (Robson et al., 1996).

The mean, minimum and maximum concentrations were calculated for the Lee main channel, tributaries and nonriver sample types using the 10-year data set and S-Plus software (Anon, 1999; Table 2). The ratios of the mean concentrations calculated for the sewage effluent, industry, fish farm and lake sample-types are presented as a ratio of the combined mean river and tributary concentrations (Table 3 ). The River Lee samples were combined to give statistics for the 11 sub-catchments, and statistics were calculated for each tributary, combining all sites available (as cited in the text). Table 4 provides data for representative reaches of the upper and lower Lee and for selected tributary sites as used in mass balance calculations. Non-river samples were pooled by sample-type prior to analyses. The summary statistics were calculated only when more than 10 data points were available, otherwise only the $10 \%$ trimmed mean was calculated. For microbiological data, the geometric mean was calculated in addition to the arithmetic mean (as it represents the true median for lognormal distributions). Summary statistics were calculated on taxonomic richness and biotic score for macrobiological data.

The time series plots were used to describe temporal trends at each site. The arithmetic mean (geometric mean for microbiological data), trimmed mean and range were given in each plot. Due to the size of the data set, only pertinent regional maps, statistics and time-series plots have been included here. The complete analysis is in Snook et al. (2002).

To investigate the relative loads of principal pollutants in the 11 sub-catchments and to assess the relative contribution from diffuse or point sources along the length of the main channel of the River Lee, a mass balance analysis of the Lee chemical data was carried out. Sewage flow rates were calculated from the population equivalent data, on the assumption of a mean flow rate per head of population of 1801 day $^{-1}$ (Table 5). The flow and quality data for the sewage works in the Lee catchment have been combined to calculate mean loads in $\mathrm{kg} \mathrm{day}^{-1}$ (Table 6). The mass loads for the river system have been calculated by multiplying the 10 year means of the Environment Agency routine water quality data by the mean flows for the river at the water quality monitoring stations over the same period, allowing for the appropriate conversion of units. The flow data for the main river sites and all the tributaries were obtained from the CEH Hydrometric register (2000). Whilst this method is likely to underestimate the true in-stream load because of a bias to water quality measurements at low flows, the method allows a first estimate to be made of the relative importance of point and diffuse pollutant sources within the Lee system.

\section{Results and Discussion}

Alkalinity, calcium, $\mathrm{PH}$

Spatial variations in the observed streamwater alkalinity, calcium concentrations and $\mathrm{pH}$ values were fairly small; for example $\mathrm{pH}$ ranged between 7.2-7.9 (site means) across the entire catchment and differences reflected variations in the underlying geology and farming intensification (Table 2 ). The mean streamwater alkalinity and calcium concentrations and $\mathrm{pH}$ values were typically highest in the north-east of the catchment which drains the Chalk. Typical alkalinities in the northern tributaries ranged between 254$285 \mathrm{mg} \mathrm{CaCO}_{3} \mathrm{l}^{-1}$ (site means for the Stort, Rib and Ash); by comparison, values in the southern section of the catchment values ranged between $150-220 \mathrm{mg} \mathrm{CaCO}_{3} \mathrm{l}^{-1}$ (site means for Turkey and Salmon Brooks, respectively).

\section{Nitrogen and phosphorus}

The principal nitrogen species in the river was nitrate, with ammonia and nitrite contributing relatively small proportions. The trimmed means for all river samples were 9.2, 0.2 and $0.1 \mathrm{mg} \mathrm{N}^{-1}$ for nitrate, ammonia and nitrite, respectively. The upper and lower Lee are both affected 


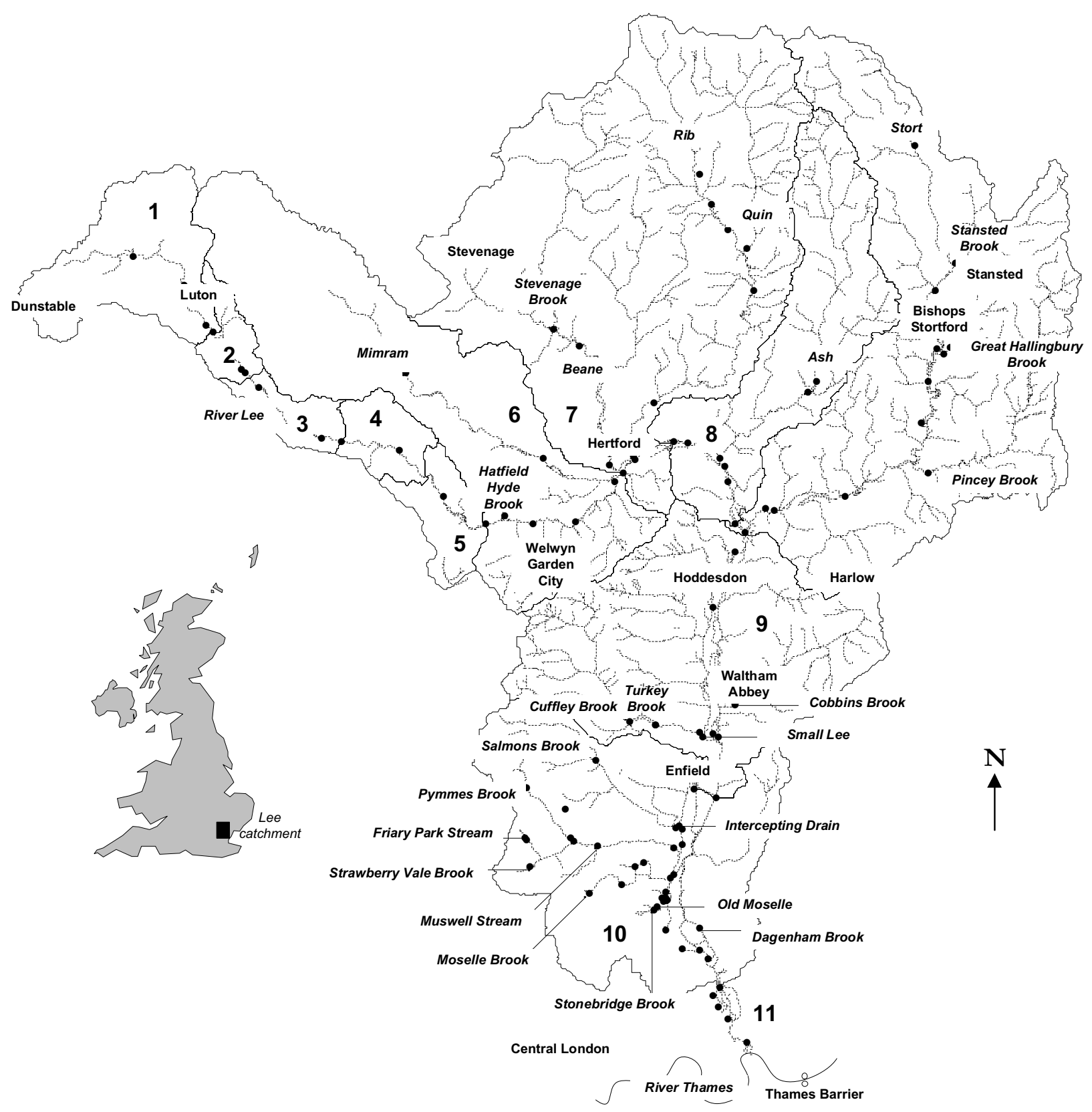

Fig. 1. The river Lee catchment. Numbers in bold refer to River Lee subcatchments. Filled circles indicate river sampling locations.

significantly by the direct discharges, with $40 \%$ and $73 \%$ respectively of nitrate-N coming from the STW direct point sources (Table 6). Thus, diffuse sources of nitrate are $60 \%$ and $27 \%$, confirming the higher proportion of diffuse nitrate from agricultural sources in the upper Lee. Some $24 \%$ of samples from the main channel of the Lee during the monitoring were in excess of the European Community standard of $11.3 \mathrm{mg} \mathrm{N}^{-1}$ (Fig. 2a).

Tributaries principally draining urban catchments, or those with substantial inputs of sewage effluent, typically exhibited higher mean nitrogen concentrations than those draining agricultural land (for example the trimmed mean nitrogen concentration for the Pymmes Brook was $10.3 \mathrm{mg}$ $\mathrm{N}^{-1}$ as compared to $5.6 \mathrm{mg} \mathrm{N}^{-1}$ for the Mimram (pooled samples). Nitrate inputs from direct industrial point sources within the catchment were typically less than $7 \mathrm{mg} \mathrm{N} \mathrm{1}^{-1}$, though mean ammonia effluent concentrations are approximately three times those observed in stream samples. Many industrial discharges are routed through sewers to STWs (mean ammonia concentration in sewage effluent was 
Water quality and ecology of the River Lee: mass balance and a review of temporal and spatial data

Table 2 Summary statistics for principal determinands (Mean, min-max) $)^{1}$ for each sample type (using pooled data within each category).

\begin{tabular}{|c|c|c|c|c|c|c|}
\hline Determinand & Rivers (Lee) & Rivers (tribs.) & Sewage & Industrial & Fish farm & Lake \\
\hline Alkalinity $\left(\mathrm{mg} \mathrm{CaCO}_{3} 1^{-1}\right)$ & $221(189-259)$ & $242(149-285)$ & $242(197-341)$ & ND & $282(282-282)$ & ND \\
\hline Ammonia $\left(\mathrm{mg} \mathrm{N} \mathrm{l}^{-1}\right)$ & $0.30(0.08-0.77)$ & $0.30(0.05-4.33)$ & $7.98(0.35-45.8)$ & $1.040 .60-1.97) 0.11$ & $(0.10-0.11)$ & $5.92(0.14-11.7)$ \\
\hline $\mathrm{BOD}\left(\mathrm{mg} \mathrm{l}^{-1}\right)$ & $2.4(1.7-3.3)$ & $2.4(1.5-4.8)$ & $16.8(1.9-127.0)$ & $13.5(1.7-29.7)$ & $1.9(1.8-2.0)$ & $8.0(7.6-8.5)$ \\
\hline Boron $\left(\mu \mathrm{g} \mathrm{l}^{-1}\right)$ & $421(200-665)$ & $270(100-626)$ & $916(724-1119)$ & ND & ND & ND \\
\hline Carbon (organic, $\mathrm{mg}^{-1}$ ) & $7.01(4.4-10.4)$ & ND & ND & ND & ND & ND \\
\hline Calcium $\left(\mathrm{mg} \mathrm{l}^{-1}\right)$ & $116(88-131)$ & $128(75-143)$ & $142(142-142)$ & ND & ND & ND \\
\hline Chlorophyll a ( $\left.\mu \mathrm{g} \mathrm{l}^{-1}\right)$ & $18.1(3.2-38.5)$ & $20.3(3.6-53.7)$ & ND & ND & ND & ND \\
\hline Chloride $\left(\mathrm{mg} \mathrm{l}^{-1}\right)$ & $166(51-926)$ & $66(26-134)$ & $139(48-419)$ & $176(30-570)$ & $33.8(33.8-33.9)$ & $191(85-298)$ \\
\hline Nitrogen (oxidised, $\mathrm{m} \mathrm{N}^{-1}$ ) & $9.2(3.8-13.6)$ & $8.0(3.2-18.5)$ & $17.4(1.6-41.1)$ & $5.0(2.7-7.0)$ & $6.4(5.1-7.6)$ & $3.7(2.5-4.9)$ \\
\hline Nitrate $\left(\mathrm{mg} \mathrm{N} \mathrm{l}^{-1}\right)$ & $9.3(7.4-11.1)$ & ND & ND & $0.10(0.10-0.10)$ & ND & ND \\
\hline Nitrite $\left(\mathrm{mg} \mathrm{N}^{-1}\right)$ & $0.10(0.04-0.35)$ & $0.17(0.03-0.76)$ & ND & ND & ND & ND \\
\hline $\mathrm{DO}\left(\mathrm{mg} \mathrm{O}_{2} \mathrm{l}^{-1}\right)$ & $9.5(5.4-13.2)$ & $9.7(6.1-12.5)$ & $7.4(3.0-12.3)$ & $9.5(8.2-10.8)$ & $10.2(9.7-10.8)$ & $10.3(10.3-10.4)$ \\
\hline DO (\% saturation) & $89(52-125)$ & $89(58-116)$ & $71.2(11.5-96.0)$ & $91.8(85.5-98.0)$ & $91.4(88.2-94.5)$ & $90.8(87.3-94.2)$ \\
\hline Orthophosphate ( $\left.\mathrm{mg} \mathrm{P}^{-1}\right)$ & $2.34(0.20-5.16)$ & $1.02(0.08-5.01)$ & $7.40(0.6-12.1)$ & $0.36(0.07-0.62)$ & $0.27(0.06-0.48)$ & $0.98(0.63-1.33)$ \\
\hline $\mathrm{pH}$ & $7.9(7.5-8.3)$ & $7.9(7.2-8.2)$ & $7.7(7.3-8.0)$ & $7.7(7.2-8.4)$ & $7.9(7.7-8.1)$ & $7.8(7.7-7.9)$ \\
\hline $\begin{array}{l}\text { Phosphate phosphorus } \\
\qquad\left(\mathrm{mg} \mathrm{P} \mathrm{l}^{-1}\right)\end{array}$ & $2.20(0.22-3.70)$ & $1.10(0.44-1.76)$ & ND & ND & ND & ND \\
\hline Silicon dioxide $\left(\mathrm{mg} \mathrm{l}^{-1}\right)$ & $12.8(10.5-14.7)$ & ND & ND & ND & ND & ND \\
\hline Suspended solids $\left(\mathrm{mg} \mathrm{l}^{-1}\right)$ & $43(8-194)$ & $35(5-318)$ & $24(3-300)$ & $36(12-88)$ & $11(9-13)$ & $17.5(8.6-26.3)$ \\
\hline Water temperature $\left({ }^{\circ} \mathrm{C}\right)$ & $12.8(11.1-15.0)$ & $11.6(7.6-16.4)$ & $13.3(5.0-19.8)$ & $13.4(10.2-17.3)$ & $10.5(10.5-10.6)$ & $10.2(9.5-10.9)$ \\
\hline Cadmium $\left(\mu \mathrm{g}^{-1}\right)$ & $0.29(0.1-0.5)$ & $0.38(0.10-0.79)$ & $0.45(0.14-0.70)$ & $0.10(0.10-0.10)$ & ND & $0.20(0.20-0.20)$ \\
\hline Copper $\left(\mu \mathrm{g} \mathrm{l}^{-1}\right)$ & $17.5(4.6-93.9)$ & $12.0(4.1-82.3)$ & $32.8(5.5-123.8)$ & $1.6(1.5-1.7)$ & ND & $5.4(5.4-5.4)$ \\
\hline Iron $\left(\mu \mathrm{g} \mathrm{l}^{-1}\right)$ & $237(90-456)$ & $322(50-1040)$ & $59(35-83)$ & $377(358-396)$ & ND & ND \\
\hline Lead $\left(\mu \mathrm{g}^{-1}\right)$ & $10.6(2.9-59.4)$ & $19.9(0.8-94.3)$ & $13.7(0.6-43.5)$ & $0.6(0.4-0.8)$ & ND & $0.9(0.9-0.9)$ \\
\hline Mercury $\left(\mu \mathrm{g} \mathrm{l}^{-1}\right)$ & $0.05(0.01-0.07)$ & $0.04(0.01-0.10)$ & $0.05(0.03-0.05)$ & ND & ND & ND \\
\hline Nickel $\left(\mu \mathrm{g} \mathrm{l}^{-1}\right)$ & $11.3(5 \cdot 0-21.1)$ & $13.7(4.9-31.9)$ & $13.0(8.2-20.0)$ & $5.0(5.0-5.0)$ & ND & $5.0(5.0-5.0)$ \\
\hline $\operatorname{Zinc}\left(\mu \mathrm{g} \mathrm{l}^{-1}\right)$ & $49(12-253)$ & $38(7-295)$ & $54.6(19.3-164.1)$ & $15.0(7.0-23.0)$ & ND & $46.0(46.0-46.0)$ \\
\hline Atrazine $\left(\mu \mathrm{g} \mathrm{l}^{-1}\right)$ & $0.18(0.03-0.55)$ & $0.04(0.004-0.071)$ & $0.09(0.09-0.09)$ & ND & ND & ND \\
\hline Chlortoluron $\left(\mu \mathrm{g} \mathrm{l}^{-1}\right)$ & $0.55(0.28-0.86)$ & $1.86(1.86-1.86)$ & ND & ND & ND & ND \\
\hline Dieldrin $\left(\mu \mathrm{g} \mathrm{l}^{-1}\right)$ & $0.005(0.002-0.008)$ & $0.001(0.001-0.001$ & ) $0.01(0.01-0.02)$ & ND & ND & ND \\
\hline Diuron $\left(\mu \mathrm{g} \mathrm{l}^{-1}\right)$ & $0.33(0.23-0.51)$ & $0.11(0.11-0.11)$ & ND & ND & ND & ND \\
\hline HCH Gamma $\left(\mu \mathrm{g} \mathrm{l}^{-1}\right)$ & $0.017(0.06-0.032)$ & $0.037(0.005-0.136)$ & $0.03(0.01-0.05)$ & ND & ND & ND \\
\hline Isoproturon $\left(\mu \mathrm{g} \mathrm{l}^{-1}\right)$ & $0.24(0.20-0.28)$ & $0.34(0.34-0.34)$ & ND & ND & ND & ND \\
\hline Linuron $\left(\mu \mathrm{g}^{-1}\right)$ & $0.22(0.07-0.70)$ & $0.95(0.07-1.83)$ & ND & ND & ND & ND \\
\hline Pentachlorophenol $\left(\mu \mathrm{g} \mathrm{l}^{-1}\right)$ & $0.20(0.08-0.43)$ & $0.42(0.42-0.42)$ & $0.18(0.05-0.33)$ & ND & ND & ND \\
\hline Simazine $\left(\mu \mathrm{g}^{-1}\right)$ & $0.14(0.06-0.40)$ & $0.042(0.042-0.047)$ & $0.10(0.10-0.10)$ & ND & ND & ND \\
\hline $\begin{array}{l}\text { 1,1,1-Trichloroethane } \\
\left(\mu \mathrm{g} \mathrm{l}^{-1}\right)\end{array}$ & $0.35(0.17-0.60)$ & $21.2^{2}(0.14-145.50)$ & $1.16(0.60-1.81)$ & ND & ND & ND \\
\hline Trichloroethene $\left(\mu \mathrm{g}^{-1}\right)$ & $0.31(0.13-0.68)$ & $1.39^{3}(0.08-4.40)$ & $1.13(0.41-2.84)$ & ND & ND & ND \\
\hline
\end{tabular}

${ }^{1}$ Mean, minimum and maximum refer to the mean of means for each site within each sample type category, mean of minimums and mean of maximums.

${ }^{2}$ When excluding a single sample from Trinity Marsh Ditch from the mean calculation values are $0.41(0.14-1.50)$

${ }^{3}$ When excluding a single sample from Trinity Marsh Ditch from the mean calculation values are 0.89 (0.08-4.23).

ND indicates no data were available.

about eight times that in industrial effluent).

Seasonal trends in streamwater nitrogen concentrations suggest a domination of diffuse nitrogen inputs in the tributaries to the north and north-east of the catchment where concentrations peaked in the winter months (Fig. 3). These seasonal patterns may, in part, be due to in-stream denitrification, as demonstrated by Whitehead and Williams (1984) for the River Thames. Temporal trends in streamwater nitrogen concentrations in watercourses in receipt of STW effluent were typically more erratic than those draining principally agricultural land; peaks in concentration occurred in summer when there is less dilution.
The highest phosphorus concentrations in the system were observed in the upper and lower Lee and the Great Hallingbury, Pymmes and Salmon Brooks due to effluent inputs from Deephams, Rye Meads, Luton East Hyde, Hatfield Mill Green and Bishops Stortford STWs (Fig. 2b). The upper Lee tributaries of the Beane, Mimram and the Ash are not affected by major STWs. The proportion of phosphorus from STWs increases from approximately $36 \%$ to $80 \%$ between the upper and lower Lee. This reflects the higher urban sources of phosphorus in the lower catchment. The estimated diffuse sources of phosphorus are, therefore, approximately $64 \%$ and $20 \%$ in the upper and lower Lee 
Table 3. Mean ${ }^{1}$ concentration of principal determinands in river samples and the ratios of the mean concentrations for other sample types to the mean river concentrations.

\begin{tabular}{|c|c|c|c|c|c|}
\hline Determinand & Rivers mean conc. & Sewage: River & Industry: River & Fish farm: River & Lake: River \\
\hline Alkalinity $\left(\mathrm{mg} \mathrm{CaCO}_{3} 1^{-1}\right)$ & 235 & 1.0 & & 1.2 & \\
\hline Ammonia $\left(\mathrm{mg} \mathrm{N}^{-1}\right)$ & 0.30 & 26.6 & 3.5 & 0.4 & 19.7 \\
\hline $\mathrm{BOD}\left(\mathrm{mg} \mathrm{l}^{-1}\right)$ & 2.4 & 7.1 & 5.7 & & 3.4 \\
\hline Boron $\left(\mu \mathrm{g} \mathrm{l}^{-1}\right)$ & 358 & 2.6 & & 0.0 & \\
\hline Calcium $\left(\mathrm{mg} \mathrm{l}^{-1}\right)$ & 124 & 1.1 & & & \\
\hline Chloride (mg l-1) & 98 & 1.4 & 1.8 & 0.3 & 2.0 \\
\hline Nitrogen (oxidised, $\mathrm{mg} \mathrm{l}^{-1}$ ) & 8.4 & 2.1 & 0.6 & 0.8 & 0.4 \\
\hline Nitrate (mg N 1-1) & 9.3 & & 0.0 & & \\
\hline $\mathrm{DO}\left(\mathrm{mg} \mathrm{O}_{2} \mathrm{l}^{-1}\right)$ & 9.7 & 0.8 & 1.0 & 1.1 & 1.1 \\
\hline DO (\% saturation) & 89 & 0.8 & 1.0 & 1.0 & 1.0 \\
\hline Orthophosphate (mg P $\left.~^{-1}\right)$ & 1.44 & 5.2 & 0.3 & 0.2 & 0.7 \\
\hline $\mathrm{pH}$ & 7.9 & 1.0 & 1.0 & 1.0 & 1.0 \\
\hline Suspended solids $\left(\mathrm{mg} \mathrm{l}^{-1}\right)$ & 38 & 0.6 & 1.0 & 0.3 & 0.5 \\
\hline Water temperature $\left({ }^{\circ} \mathrm{C}\right)$ & 11.9 & 1.1 & 1.1 & 0.9 & 0.9 \\
\hline Cadmium $\left(\mu \mathrm{g} \mathrm{l}^{-1}\right)$ & 0.34 & 1.3 & 0.3 & & 0.6 \\
\hline Copper $\left(\mu \mathrm{g}^{-1}\right)$ & 13.7 & 2.4 & 0.1 & & 0.4 \\
\hline Iron $\left(\mu \mathrm{g} \mathrm{l}^{-1}\right)$ & 274 & 0.2 & 1.4 & & \\
\hline Lead $\left(\mu \mathrm{g}^{-1}\right)$ & 15.3 & 0.9 & 0.0 & & 0.1 \\
\hline Mercury $\left(\mu \mathrm{g}^{-1}\right)$ & 0.04 & 1.1 & & & \\
\hline Nickel $\left(\mu \mathrm{g} \mathrm{l}^{-1}\right)$ & 12.5 & 1.1 & 0.4 & & 0.4 \\
\hline $\operatorname{Zinc}\left(\mu \mathrm{g}^{-1}\right)$ & 42 & 1.3 & 0.4 & & 1.1 \\
\hline Atrazine $\left(\mu \mathrm{g} \mathrm{l}^{-1}\right)$ & 0.15 & 0.6 & & & \\
\hline Dieldrin $\left(\mu \mathrm{g} \mathrm{l}^{-1}\right)$ & 0.004 & 2.3 & & & \\
\hline HCH Gamma ( $\left.\mu \mathrm{g} \mathrm{l}^{-1}\right)$ & 0.03 & 1.1 & & & \\
\hline Pentachlorophenol $\mu \mathrm{g} \mathrm{l}^{-1}$ ) & 0.23 & 0.8 & & & \\
\hline Simazine $\left(\mu \mathrm{g} \mathrm{l^{-1 }}\right)$ & 0.11 & 0.9 & & & \\
\hline $1,1,1$-Trichloroethane $\left(\mu \mathrm{g} \mathrm{l}^{-1}\right)$ & $10.78(0.41)^{2}$ & $0.1(2.8)^{2}$ & & & \\
\hline Trichloroethene $\left(\mu \mathrm{g} \mathrm{l}^{-1}\right)$ & $0.85(0.58)^{2}$ & $1.3(2.0)^{2}$ & & & \\
\hline
\end{tabular}

River samples from the Lee and tributaries have been combined. Determinands only sampled in river samples have been omitted.

1. Mean indicates the mean of the site means within each sample type.

${ }^{2}$ Values in parentheses indicate means and ratios calculated excluding a single sample from Trinity Marsh Ditch from the data set.

Table 4. Mean concentrations for selected determinands on the River Lee and tributaries.

\begin{tabular}{|c|c|c|c|c|c|c|c|c|}
\hline Watercourse & $Q$ & $\mathrm{NO}_{3}-\mathrm{N}$ & $\mathrm{NH}_{4}-\mathrm{N}$ & $P$ & $\mathrm{Cl}$ & $P b$ & $C u$ & $C d$ \\
\hline Upper Lee & 1.25 & 13.3 & 0.36 & 5.16 & 122.1 & & & \\
\hline Lower Lee & 5.54 & 11.9 & 0.85 & 3.70 & 98.6 & 59.4 & 93.9 & 0.35 \\
\hline Ash & 0.32 & 6.3 & 0.08 & 0.38 & 38.1 & & 5.0 & \\
\hline Beane & 0.56 & 5.4 & 0.06 & 0.13 & 36.7 & & 6.3 & \\
\hline Cobbins Brook & 0.22 & 10.0 & 0.14 & 0.82 & 82.7 & & & \\
\hline Mimram & 0.52 & 5.2 & 0.05 & 0.13 & 29.4 & & 5.0 & \\
\hline Pymmes Brook & 0.53 & 4.2 & 0.47 & 0.77 & 85.2 & 94.3 & 82.3 & 0.79 \\
\hline Rib & 0.63 & 6.1 & 0.06 & 0.31 & 34.3 & & 8.1 & \\
\hline Salmon Brook & 0.14 & 5.3 & 0.58 & 0.64 & 73.0 & 15.2 & 24.7 & 0.70 \\
\hline Small River Lee & 0.33 & 6.1 & 0.23 & 0.57 & 72.3 & & & \\
\hline Stort & 1.34 & 7.1 & 0.06 & 0.96 & 65.0 & 2.7 & 5.9 & \\
\hline Turkey Brook & 0.20 & 4.4 & 0.12 & 0.30 & 73.6 & & & \\
\hline \multicolumn{9}{|c|}{ Q refers to discharge in $\mathrm{m}^{3} \mathrm{~s}^{-1}$} \\
\hline
\end{tabular}


Water quality and ecology of the River Lee: mass balance and a review of temporal and spatial data

Table 5. Mean concentrations for selected determinands for principal STWs in the Lee catchment. PE refers to population equivalent.

\begin{tabular}{|c|c|c|c|c|c|c|c|c|c|}
\hline$S T W$ & Receiving watercourse & $P E$ & $\mathrm{NO}_{3}-\mathrm{N}$ & $\mathrm{NH}_{4}-\mathrm{N}$ & $P$ & $\mathrm{Cl}$ & $P b$ & $\mathrm{Cu}$ & $C d$ \\
\hline Barkway & Quin & 780 & 31.3 & 0.85 & 7.38 & 121.4 & & & \\
\hline Bishops Stortford & Great Hallingbury Brook & 29758 & 21.3 & 0.92 & 5.84 & 122.7 & 3.2 & 7.9 & 0.36 \\
\hline Braughing & Quin & 1832 & 29.7 & 1.09 & 9.03 & 131.3 & & & \\
\hline Brickenden & Tributary of Bayford Brook & 227 & 24.9 & 2.27 & 6.99 & 115.9 & & & \\
\hline Buntingford & Rib & 5054 & 29.5 & 0.35 & 7.08 & 88.8 & 0.6 & 26.4 & 0.14 \\
\hline Clavering & Stort & 1593 & 26.4 & 0.53 & 7.23 & 124.0 & & & 0.50 \\
\hline Cottered & Cottered Brook & 610 & 25.8 & 1.41 & 5.76 & 162.2 & & & 0.50 \\
\hline Dane End & Beane & 814 & 36.5 & 0.64 & 6.84 & 104.2 & & & 0.38 \\
\hline Deephams & Salmon Brook & 774557 & 16.8 & 0.55 & 5.54 & 128.8 & 13.8 & 14.3 & 0.46 \\
\hline Harpenden & Lee & 35006 & 25.6 & 2.17 & 9.01 & 136.1 & & & 0.45 \\
\hline Hatfield (Mill Green) & Tributary of Lee & 16804 & 24.3 & 0.96 & 8.17 & 108.7 & 3.6 & 54.7 & 0.38 \\
\hline Hatfield Heath & Tributary of Pincey Brook & 2284 & 17.2 & 0.86 & 6.37 & 144.9 & & & \\
\hline Little Hallingbury & Tributary of Stort & 1296 & 22.9 & 5.06 & 8.20 & 184.1 & & & \\
\hline Luton (East Hyde) & Lee & 130393 & 17.6 & 1.15 & 6.23 & 121.7 & 4.0 & 11.0 & 0.31 \\
\hline Manunden & Stort & 707 & 26.0 & 0.92 & 8.27 & 163.7 & & & 0.50 \\
\hline Rye Meads & Toll House Stream & 340864 & 14.6 & 0.97 & 6.73 & 132.9 & 3.1 & 18.9 & 0.61 \\
\hline Standon & Rib & 4658 & 33.4 & 0.51 & 7.44 & 133.3 & & & \\
\hline Standsted Mountfitchet & Stort & 8348 & 26.6 & 0.51 & 7.89 & 105.8 & & & \\
\hline Takely & Pincey Brook & 1548 & 22.7 & 1.76 & 7.67 & 160.7 & & & 0.50 \\
\hline Therfield Chapel Green & Rib & 749 & 26.7 & 0.80 & 5.41 & 129.7 & & & \\
\hline Widford and Wareside & Ash & 2605 & 23.6 & 0.60 & 8.94 & 75.5 & & & \\
\hline
\end{tabular}

indicating the relatively higher diffuse and agricultural inputs into the upper catchment. For the relatively rural catchments, namely those of the Beane, the Ash, the Stort and the Rib, diffuse sources dominate as the estimated percentage of nitrate and phosphorus from the direct discharges are approximately $12 \%$ and $45 \%$, respectively.

\section{Biological oxygen demand and oxygen saturation}

Along the main stem of the Lee, mean BOD values for the 11 sub-catchments ranged between 1.6 and $2.7 \mathrm{mg} \mathrm{O}_{2} \mathrm{l}^{-1}$ and within the wider catchment watercourse means ranged between 1.5 and $4 \mathrm{mg} \mathrm{O}_{2} \mathrm{l}^{-1}$ (trim means). Values were typically higher in urbanised than agricultural watercourses (between 3 and $4 \mathrm{mg} \mathrm{O}_{2} \mathrm{l}^{-1}$ were typical trimmed means for urbanised tributaries within the catchment).

STW effluent was the principal point source input of BOD within the catchment (Table 3). Typically, effluent from smaller STWs exhibited higher BOD concentrations than that from major works. For example, mean BOD in effluent from the Navigation Inn STW was $127 \mathrm{mg} \mathrm{O} \mathrm{l}^{-1}$, which exceeds the maximum permitted BOD for sewage effluent of $20 \mathrm{mg} \mathrm{O}_{2} \mathrm{l}^{-1}$ assuming an 8:1 dilution (Royal Commission, 1992). Luton Hoo Lakes surface water overflow exhibited a mean BOD of $81 \mathrm{mg} \mathrm{O}_{2} \mathrm{1}^{-1}$; despite this, no significant downstream effect was noted in the Lee itself.

In the River Lee and its tributaries, the mean dissolved oxygen concentration was $10 \mathrm{mg} \mathrm{O}_{2} \mathrm{l}^{-1}$ (89\% saturation). For individual watercourses, the trim mean values ranged between 6 and $12 \mathrm{mg} \mathrm{O}_{2} \mathrm{l}^{-1}$ (56 to $113 \%$ saturation). Dissolved oxygen concentrations in sewage effluent were on average 0.8 of those in river samples. A number of small STWs in the catchment exhibited particularly low mean oxygen concentrations. For example, Claverhambury Farm and West Essex Golf Club STWs had mean concentrations of approximately $3 \mathrm{mg} \mathrm{O}_{2} 1^{-1}$ (61 and 65\% saturation, respectively). Low concentrations were also evident in effluent from a number of larger works such as Harpenden STW with mean levels of $5 \mathrm{mg} \mathrm{O}_{2} \mathrm{l}^{-1}$ (50\% saturation). The Pymmes and Salmon Brooks, in receipt of effluent from a large STW, typically exhibited relatively depressed mean dissolved oxygen concentrations, as did urban watercourses in the south of the catchment because of a combination of urban run-off and domestic misconnection of foul water to surface water sewers. A clear seasonal trend in dissolved oxygen concentration was evident: spring maxima were followed by autumnal lows at most sites; this timing probably reflected relative photosynthetic activity.

\section{Water temperature}

Point source inputs of relatively warm water caused local increases in a general positive longitudinal trend in water temperature downstream along the main channel. Sewage 
Table 6. Pollutant loads for major sewage discharges and river quality sites in the Lee and sub-catchments of the Lee plus percentages of point source loads.

\begin{tabular}{|c|c|c|c|c|c|c|c|}
\hline $\begin{array}{l}\text { MAIN SEWAGE WORKS } \\
\text { LOADS }\left(k g d a y^{-1}\right)\end{array}$ & $\mathrm{NO}_{3}-\mathrm{N}$ & $\mathrm{NH}_{4}$ & $P$ & $\mathrm{Cl}$ & $P b$ & $\mathrm{Cu}$ & $C d$ \\
\hline Upper Lee & 575 & 40.7 & 202.7 & 3713 & 0.09 & 0.03 & 0.04 \\
\hline Beane & 5 & 0.1 & 1.0 & 15 & & & \\
\hline Ash & 11 & 0.3 & 4.19 & 35 & & & \\
\hline Stort & 165 & 5.9 & 46.1 & 872 & & & \\
\hline Rib & 58 & 0.9 & 13.4 & 210 & & & \\
\hline Salmon & 2348 & 77.1 & 772.4 & 1796 & 1.93 & 1.98 & 0.06 \\
\hline Lower Lee & 4173 & 190.0 & 1489 & 31520 & 2.24 & 3.64 & 0.11 \\
\hline \multicolumn{8}{|l|}{ RIVER LOADS (KG DAY ${ }^{-1}$ ) } \\
\hline Upper Lee & 1431 & 38.8 & 557 & 13187 & & & \\
\hline Beane & 259 & 3.1 & 6.1 & 1777 & & & \\
\hline Ash & 174 & 2.1 & 10.5 & 1053 & & 0.14 & \\
\hline Stort & 824 & 7.4 & 110.9 & 7522 & 0.31 & 0.68 & \\
\hline Rib & 329 & 3.2 & 16.6 & 1868 & & & \\
\hline Mimram & 232 & 2.4 & 5.67 & 1322 & & 0.22 & \\
\hline Cobbins Brook & 189 & 2.7 & 15.6 & 1571 & & & \\
\hline Pymmes Brook & 329 & 3.2 & 16.7 & 1868 & & 0.44 & \\
\hline Salmon Brook & 65 & 7.0 & 7.79 & 883 & 0.18 & 2.96 & 0.01 \\
\hline Lower Lee & 5707 & 405.0 & 1771 & 47218 & 28.40 & 44.30 & 0.17 \\
\hline \multicolumn{8}{|c|}{ POINT SOURCE LOADS (PERCENTAGE) } \\
\hline Upper Lee & 40.2 & 104.0 & 36.4 & 28.1 & & & \\
\hline Beane & 2.1 & 2.9 & 16.4 & 0.8 & & & \\
\hline Ash & 6.0 & 13 & 39.9 & 3.4 & & & \\
\hline Stort & 20.3 & 79.2 & 41.6 & 11.6 & & & \\
\hline Rib & 17.7 & 26.0 & 80.7 & 11.2 & & & \\
\hline Lower Lee & 73.0 & 46.9 & 84.0 & 66.0 & 7.9 & 8.2 & 69.0 \\
\hline
\end{tabular}

effluent was the principal source of relatively warm water: an increase was evident on the Great Hallingbury Brook downstream of Bishop's Stortford STW and on the Lee downstream of Luton East Hyde STW (Tables 2 and 3). Downstream of Deephams STW, the mean water temperature in the Pymmes and Salmon Brooks was $2.6^{\circ} \mathrm{C}$ higher than in the mean river (14.6 and $12.0{ }^{\circ} \mathrm{C}$, respectively). The mean water temperature in industrial effluent was $1{ }^{\circ} \mathrm{C}$ higher than the river (trim mean $13^{\circ} \mathrm{C}$ ); a maximum single value of $34{ }^{\circ} \mathrm{C}$ was recorded from Pura Foods effluent, discharged into Bow Creek.

\section{Suspended sediment}

Suspended solid concentrations were highest in the lower reaches of the Lee (trim mean for Lee sub-catchments ranged between 6 and $\left.13 \mathrm{mg} \mathrm{l}^{-1}\right)$. Amongst the tributaries, highest values were evident in urban watercourses in receipt of sewage effluent. For example, the trimmed means in the Pymmes and Salmon Brooks were 20 times those found in other Lee tributaries (173 and $147 \mathrm{mg} \mathrm{l}^{-1}$, respectively, as compared to a mean of $8 \mathrm{mg} \mathrm{l}^{-1}$ for other tributaries combined). High peaks in suspended solid concentration ranged through the catchment from 166 to $999 \mathrm{mg} \mathrm{l}^{-1}$; mean values, therefore, must be treated with caution (data were highly skewed and dispersed relative to a normal distribution). High peaks were associated largely with storm or high flow conditions. As agricultural land use across the upper Lee is mainly arable, spatial variations in suspended sediments may be attributed to sewage discharges in any particular tributary. In the lower Lee, urban runoff and sewage flows are the major factors controlling suspended sediment levels.

\section{Silica and chlorophyll a}

Silica was monitored only in the mid- and lower reaches of the Lee, with mean concentrations between 11 and $12 \mathrm{mg} \mathrm{l}^{-1}$ $\mathrm{SiO}_{2}$. The silica concentrations in the river decreased in spring and autumn, possibly reflecting seasonal patterns in diatom growth. Mean chlorophyll a concentrations within the catchment ranged between 3 and $14 \mu \mathrm{g} \mathrm{l^{-1 }}$ (trim means) 
Water quality and ecology of the River Lee: mass balance and a review of temporal and spatial data

(a)

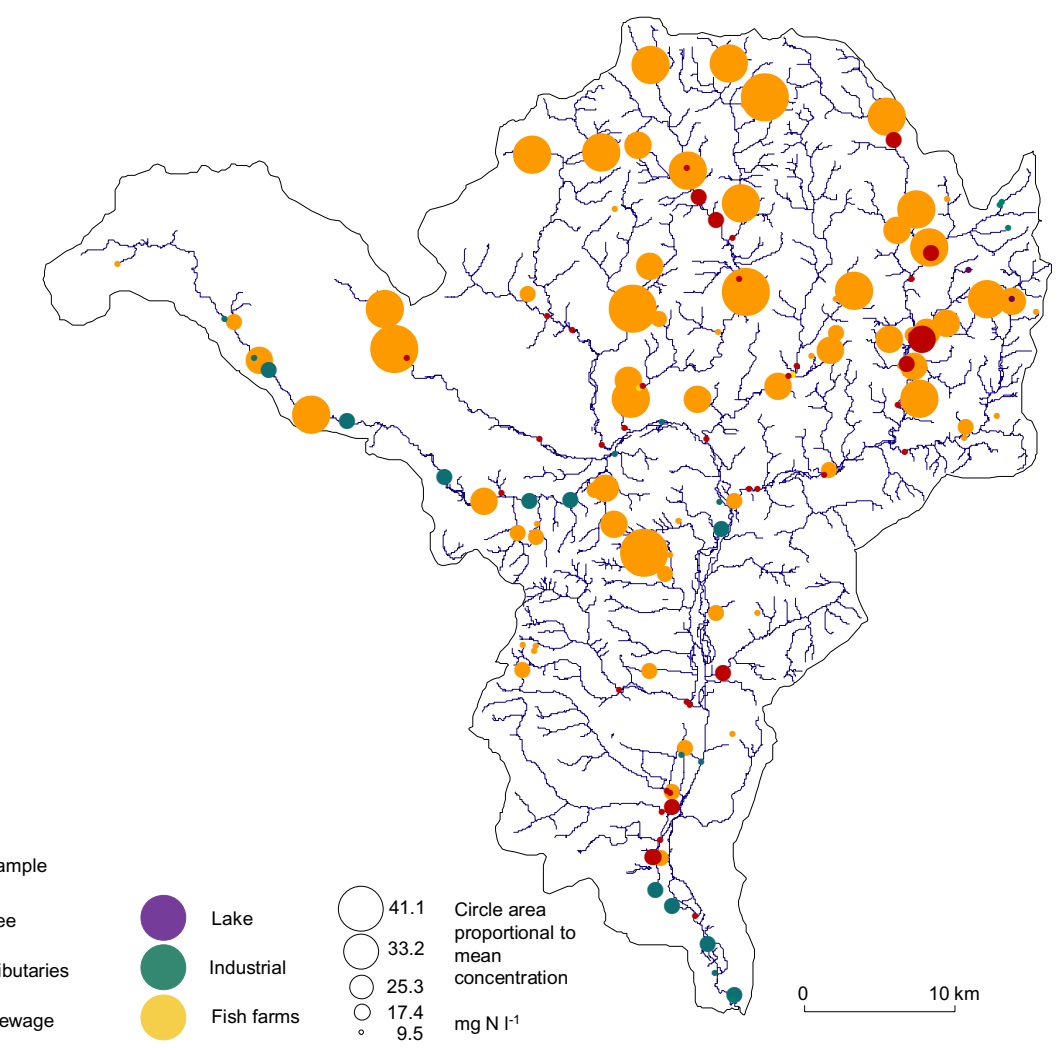

(b)

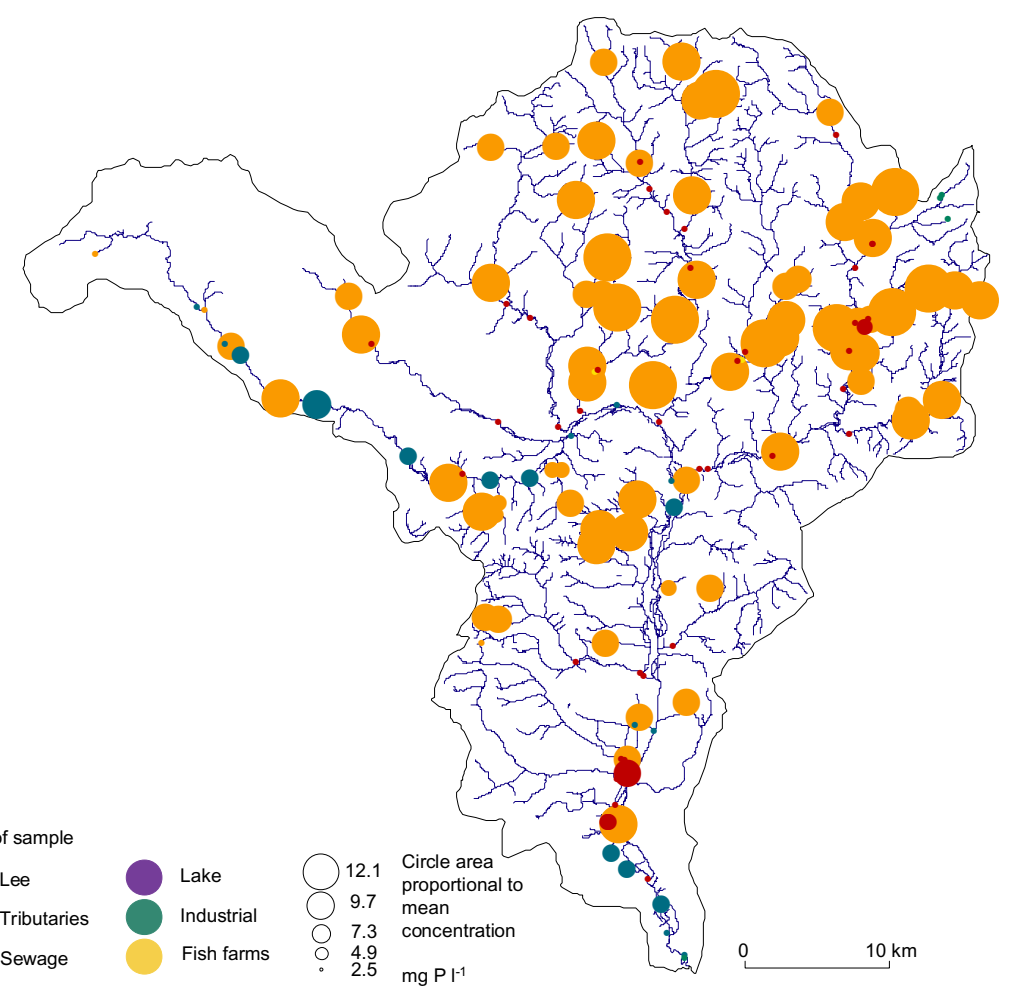

Fig. 2. Regional maps showing average concentrations of (a) nitrogen and (b) orthophosphate phosphorus. Sizes of circles are proportional to average concentration (1999 to 2000 data). Values given in legend reflect the category maximum. 
(a)

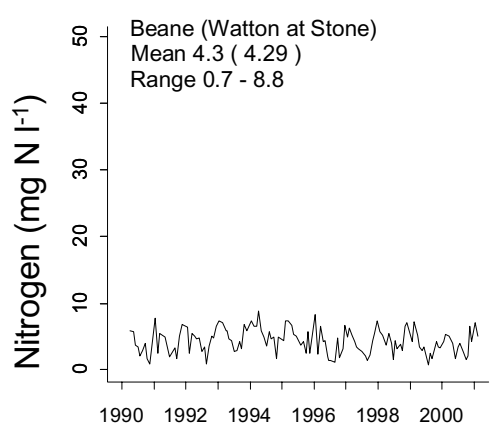

(b)

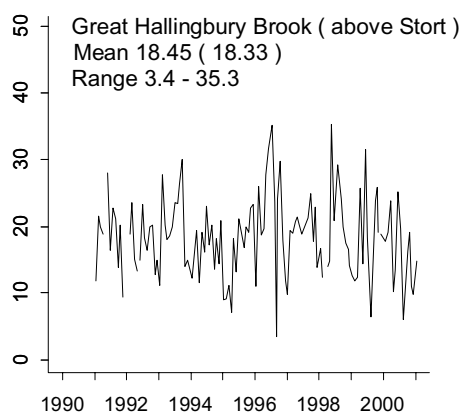

(c)

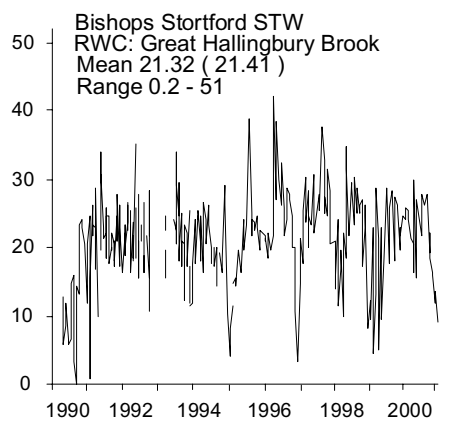

Fig. 3. Time series plots of nitrogen at selected sites within the Lee catchment. RWC refers to receiving water course for sewage treatment works effluent. (a) and (b) illustrate variability in trends between an agricutlural watercourse and an uban watercourse in receipt of sewage effluent. An example sewage effluent time-series is provided for comparison (c).

and increased throughout the catchment in summer.

\section{Metals}

Generally, concentrations of metals in the River Lee and its tributaries were below the limits recommended in the Dangerous Substances Directive Environmental Quality Standards (EQS) for freshwaters (Table 2). Notable exceptions were maximum concentrations of copper and zinc in tributaries draining urban areas and the lower reaches of the Lee typically receiving sewage effluent or urban runoff. As the number of STWs and urban areas increased down the river system, so the in-stream metals concentrations increased and $92 \%$ of lead and copper measured in the lower Lee is derived from its urban tributaries (Table 6).

The mean cadmium concentrations in the River Lee and its tributaries were below the EQS $\left(5 \mu \mathrm{g} \mathrm{l}^{-1}\right.$ annual average) (Table 2); the maximum concentration recorded in the Lee at Holwell Bridge equalled this. The Pymmes and Salmon Brooks, in receipt of the effluent from Deephams STW, had the highest cadmium concentrations in the catchment (trim mean 0.64 and $0.34 \mu \mathrm{g} \mathrm{1^{-1 }}$, respectively).

The mean in-stream copper concentration in the Lee catchment, $5.3 \mu \mathrm{g}^{-1}$, compares favourably with that in the Thames at Greenwich, $11 \mu \mathrm{g}^{-1}$ (trim mean). Luton Hoo Lakes surface water outfall exhibited a particularly high mean copper concentration $\left(124 \mu \mathrm{g}^{-1}\right)$. Maximum copper concentrations of approximately $6 \mu \mathrm{g}^{-1}$ in tributaries draining mainly agricultural land probably reflect a use of copper pesticides, fungicides or the addition of copper as a trace element.

Industrial sources, in particular Elsenham Sand Quarries in the north of the catchment, were the principal point source input of iron into the Lee (Table 3). The iron concentration in STW effluent was low, with mean values one fifth of those in river samples and stream-water iron concentrations in the catchment were generally between $105-285 \mu \mathrm{g}^{-1-}$. The high alkalinity and $\mathrm{pH}$ in the catchment may have increased iron precipitation.

STW's effluent was the principal point source of lead into the Lee catchment; river concentrations were, however, generally low (Table 2) and well below the EQS value of $250 \mu \mathrm{g}^{-1}$ annual average (as set within the context of an alkalinity for the catchment of $250 \mathrm{mg} \mathrm{CaCO}_{3} \mathrm{1}^{-1}$ ).

Within the Lee catchment mean mercury concentrations in both river and sewage samples were below the detection limit of $0.1 \mu \mathrm{g} \mathrm{l}^{-1}$; less than $5 \%$ of records were greater than this. The maximum concentration recorded in the catchment was, however, $2.8 \mu \mathrm{g} \mathrm{l}^{-1}$ (in the Lee above Ware Lock), almost three times the Dangerous Substances Directive annual average standard for mercury of $1 \mu \mathrm{g}^{-1}$.

STWs were the principal point source input of zinc into the catchment. Concentrations from larger STWs were typically higher than for smaller works. Average concentrations in effluent from three of the larger STWs in the catchment were between 4 and 5 times the river sample average (Rye Meads at $47 \mu \mathrm{g} \mathrm{1^{-1 }}$, Luton East Hyde at $52 \mu \mathrm{g}$ $1^{-1}$ and Deephams at $58 \mu \mathrm{g} \mathrm{l}^{-1}$ ). Longitudinal decreases in zinc concentrations in both the Beane and the Rib may reflect a use of zinc pesticides and fertilisers in their upper principally agricultural catchments.

\section{Micro-organics}

Micro-organic pollutants were monitored at a restricted number of river sites within the Lee catchment: typically, the mid- and lower reaches of the Lee tributaries were rarely monitored. Of the 'non-river' sample types, only STW effluent was routinely monitored for a limited number of 
micro-organic determinands. More infrequent sampling, relative to other chemical determinands, limited the interpretation of temporal trends.

Though micro-organics were widely detected in the Lee catchment (Tables 2 and 3), the mean concentrations within the streamwater of the River Lee and its tributaries were below the recommended limits given in the Dangerous Substances Directive EQS for freshwaters, though maximum recorded concentrations (up to $17 \%$ of samples for a given substance) were in excess of these standards for 10 substances.

Concentrations of atrazine and simazine (chlorotriazine herbicides) were generally below the EQS $\left(2 \mu \mathrm{g} \mathrm{l}^{-1}\right)$; less than one percent exceeded this. The magnitude and frequency of peaks in concentration declined from 1994; the use of these two chemicals was banned in nonagricultural situations in the UK in 1993. Isolated peaks in simazine concentration were, however, evident after this date.

Phenylurea herbicides analysed include chlorotoluron, diuron, isoproturon (DIIP1, 3dithiolan-2-ylidenemalonate) and linuron; more than three-quarters of river samples contained detectable levels of these substances. Within the Lee catchment, about $6 \%$ of river samples contained chlorotoluron in excess of the EQS of $2 \mu \mathrm{g} \mathrm{l}^{-1}$; about $1.6 \%$ of diuron and almost one percent of isoproturon samples were above this EQS.

Concentrations of pentachlorophenol (a fungicide, amongst other uses) were at or below the detection limit in approximately one half of river and sewage samples from the Lee catchment. Nevertheless, nearly one per cent of river samples reached or exceeded the EQS of $2 \mu \mathrm{g}^{-1}$. Relatively high concentrations were detected in effluent from Luton East Hyde and Rye Meads STW (trim means $0.3 \mu \mathrm{g} \mathrm{l}^{-1}$ ) concurrent with elevated concentrations in the adjacent river samples.

Organochlorine insecticides dieldrin, $\mathrm{HCH}$ beta and gamma were detected widely in the lower Lee catchment. $17 \%$ of river samples and $24 \%$ of sewage samples reached or exceeded the EQS $\left(0.01 \mu \mathrm{g} \mathrm{l}^{-1}\right)$ for dieldrin and approximately one percent of river and $3.5 \%$ of sewage samples exceeded the EQS for HCH gamma $\left(0.1 \mu \mathrm{g}^{-1}\right)$. Concentrations of these two determinands within individual STWs were fairly consistent across the catchment, inferring non-industrial sources of these substances.

Fumigant insecticides, tetrachloromethane (carbon tetrachloride), trichloromethane (chloroform) and tetrachloroethene were widely detected in river and, where monitored, in sewage samples within the Lee catchment. Trichloromethane concentrations reached or were in excess of the EQS $\left(5 \mu \mathrm{g} \mathrm{l}^{-1}\right)$ in $6 \%$ of river (mid- and lower Lee) and $8 \%$ of sewage samples. Levels were particularly erratic in effluent from Deephams STW during the mid 1990s (range 0.3 to $153 \mu \mathrm{g} \mathrm{l}^{-1}$ ) where a maximum level was over 30 times the EQS. Concentrations were typically higher in smaller, largely urban, watercourses than in the main stem of the Lee.

Industrial solvents, degreasing, cleaning type liquids sampled within the Lee catchment were 1,1,1trichloroethane and trichloroethene. Both were detectable in most river and sewage samples. Trichloroethene concentrations exceeded the EQS in some one percent of river samples (EQS $10 \mu \mathrm{g} \mathrm{l}^{-1}$ ). Smaller watercourses generally exhibited higher concentrations than the main stem of the Lee.

\section{BIOLOGICAL QUALITY OF THE LEE CATCHMENT}

Based on the spatial variations in biological indices, three distinct geographical areas can be defined, corresponding to nutrient levels, degree of urbanisation and habitat modification within the catchment:

\section{Upper reaches of the Lee}

Microbiological data indicated poor water quality in the upper reaches of the Lee in terms of total and faecal coliform concentrations ( 95 percentile 152500 and 16905 coliforms $100 \mathrm{ml} \mathrm{s}^{-1}$, respectively); these values represent 15 and 8 times the EC Bathing Water Directive standards (95P 10000 and 2000 coliforms $100 \mathrm{ml} \mathrm{s}^{-1}$ ), respectively.

Macrobiological water quality, in terms of taxonomic richness and total and mean biotic scores, was poorest at the two most upstream sites sampled, Sundon and Luton (e.g., mean richness of 9 taxa and BMWP score of 23 at Luton). Urban drainage from the towns of Dunstable and Luton may compound the effects of an already largely altered flow regime in the watercourse. No substantial fisheries data were available for the upper catchment.

\section{Mid Lee and tributaries}

The mid-reaches of the Lee exhibited relatively low coliform and streptococci content. At best (sub-catchment 8), total coliform concentrations narrowly exceeded the EC Bathing Water Directive standard (11 509 coliforms $100 \mathrm{ml} \mathrm{s}^{-1}$ ) whilst faecal coliform concentrations were within these standards (1784 coliforms $100 \mathrm{mls}^{-1}$ ); no limits have been set for faecal streptococci. All microbial determinands sampled exceeded Environment Agency guideline limits. Between 1996 and 2001, salmonella were detected in this section of the Lee. No data were available for tributaries in the north and north-east of the catchment.

In general, tributaries in the agricultural north-east of the 
catchment exhibited higher macrobiological GQA grades than their southern counterparts or the main stem of the Lee. In tributaries such as the Ash, Beane and Rib in the north of the catchment, there was a longitudinal increase in biotic score. The location of STWs in the upper reaches of some tributaries may contribute to this trend, e.g. Buntingford STW on the Rib. Dilution of nutrient-rich point sources farther downstream may encourage a more diverse fauna. Without comparative upstream ecological data on these watercourses, this can, however, only be inferred.

Longitudinal trends in chemical determinands on the Rib (a watercourse where sufficient data sites were available) indicated nutrient concentrations which largely supported this hypothesis. An increase in biotic scores in the lower reaches of the Rib reflected an increased abundance of organic pollution-intolerant animals in the waterbody. In the Rib tributary, maximum mean nitrogen and orthophosphate phosphorus concentrations and biological oxygen demand were recorded downstream of Buntingford STW; thereafter, concentrations declined to values comparable with those upstream of the effluent input (the mean concentrations for the site immediately downstream of the sewage effluent and the site farthest downstream were, for $\mathrm{N}$, from 17 to $7 \mathrm{mg} \mathrm{l}^{-1}$, P 2.4 to $0.3 \mathrm{mg} \mathrm{l}^{-1}$ and BOD 1.9 to $1.6 \mathrm{mg} \mathrm{l}^{-1}$ ).

On the main stem of the Lee, biotic scores indicated minimum organic pollution mid-catchment between Waterhall and Enfield Weir (maximum richness of 37 taxa and BMWP score of 157, trim means for sub-catchment). This mid-catchment section of the Lee receives water from the largely agricultural watercourses to the north and northeast. The fauna recorded within non-urbanised sections of upper and mid-reaches of the Lee reflect the presence of an unmodified physical habitat within the watercourse, with the occurrence of taxa favouring both weedy or ponded areas, such as Alder-flies (Sialidae) and stony or flowing habitats, such as the Sand-sedge (Rhyacophilidae), Blacksedge (Goeridae) and Willow-flies (Leuctridae); these are present only in these mid-reaches.

Within the Lee catchment, two sections of river were designated salmonid fisheries, the Mimram and a reach of the Rib including the adjoining Quin. The Ash, Beane, Pincey, Rib, Stort, mid-Lee and Lee Navigation were designated cyprinid fisheries. The designated salmonid and cyprinid fisheries were typically in compliance with the Freshwater Fisheries Directive standards when considering annual mean concentrations of the chemical determinands, although on occasion maximum concentrations were in excess of standards: for the salmonid fisheries, the maximum suspended solids and copper concentrations and water temperature exceeded the standards whilst, for the cyprinid fisheries, the maximum ammonia, suspended solids and zinc concentrations were in excess. The Freshwater Fisheries Directive guideline mean copper concentrations for salmonid fisheries in watercourses of hardness $500 \mathrm{mg}$ $\mathrm{CaCO}_{3} \mathrm{l}^{-1}$ (mean hardness for the Lee was $322 \mathrm{mg} \mathrm{CaCO}_{3} \mathrm{l}^{-1}$ ) is $0.112 \mathrm{mg}^{-1}$; mean values for watercourses designated as salmonid fisheries within the catchment were between 0.005 and $0.01 \mathrm{mg} \mathrm{l}^{-1}$ but maximum values were between 2 and 5 times this limit. Copper is known to be harmful to some invertebrates in far lower concentrations than those quoted for fish. Maund et al. (1992) found the lowest observed effect concentration (LOEC) for population density for the freshwater amphipod crustacean Gammarus pulex (Linnaeus), the freshwater shrimp, widely distributed in the catchment, to be $14.6 \mu \mathrm{g} \mathrm{l}^{-1}$. In the mid-catchment, the mean 95 percentile concentration was in excess of this value on the $\operatorname{Rib}\left(18 \mu \mathrm{g} \mathrm{l}^{-1}\right)$.

\section{Lower Lee, Lee Navigation and tributaries}

Microbiological data for the southern part of the catchment indicated a decline in water quality relative to the midreaches. The highest concentrations of microbial determinands were found in the most downstream reach of the Lee. Coliform concentrations far exceeded EC Bathing Water Directive standards with values 71 and 59 times this standard for total and faecal coliforms (95P 710000 and 117000 coliforms per $100 \mathrm{ml} \mathrm{s}^{-1}$, respectively); mean faecal streptococci were 922 streptococci per $100 \mathrm{ml} \mathrm{s}^{-1}$ (trim mean). The highest number of positive occurrences of Salmonella was recorded in the Lee within the farthest downstream reach sampled (at Carpenters Road between 1996 and 2001). Such high microbiological content within the lower Lee will inevitably affect the suitability of the watercourse for recreational purposes.

Tributary sites within the lower Lee sub-catchments typically exhibited higher mean coliform concentrations than sites on the main stem of the River Lee. The Dagenham and Moselle Brooks and Friary Park Stream exhibited total coliform concentrations more than 100 times, and faecal coliforms between 343 and 573 times the EC Bathing Water Directive standard. Such high coliform concentrations in watercourses not in receipt of STW effluent infers an alternative source; the misconnection of foul water to surface water sewers and combined sewage overflows within this area may be one possibility.

Within the lower reaches of the Lee, the macrobiological water quality was substantially below that recorded in the mid-reaches, reaching a minimum at Carpenters Road (mean richness 9 taxa, BMWP score 24); biological GQA grade E (biological water quality substantially worse than predicted with fauna restricted to organic pollution tolerant families). 
Some tributaries were likewise grade E (e.g. the Pymmes and Cobbins Brooks). The Lee Navigation, by contrast, typically exhibited fauna similar to those predicted for a river of its character (grade A). The mean BMWP scores for urban watercourses within the catchment were typically as low as 50 or less; this compares with scores typically over 100 for the agricultural watercourses.

The longitudinal trend in biotic scores between mid- and lower reaches of the Lee and, hence, the relative dominance of pollution tolerant individuals, was concurrent with the spatial variations in the nutrient concentrations. Between the mid- and lower reaches (sub-catchments 8 and 10), mean levels of ammonia, nitrate and orthophosphate phosphorus increased by 5, 1.4 and 2.5 times, respectively. Dissolved oxygen fell by approximately one quarter and biological oxygen demand rose by 1.5 times $\left(1.8\right.$ to $2.8 \mathrm{mg} \mathrm{l}^{-1}$, respectively). Mean suspended solid concentrations doubled between these reaches (12.1 to $24.5 \mathrm{mg} \mathrm{l}^{-1}$, respectively); such trends will affect the presence of gill-bearing and filterfeeding animals. The Salmon Brook exhibited a longitudinal decline in macrobiological water quality, of which the most downstream site sampled was below Deephams STW with an average BMWP of only 32. This trend was likewise concurrent with raised nutrient and depressed oxygen levels in the watercourse.

Within the Lee catchment, the occurrence of degraded habitat and diffuse pollution are cited as principal causes for the lack of suitability for fish communities (Environment Agency, 2001a,b). Reaches within the catchment not designated as either salmonid or cyprinid fisheries frequently failed to meet the mandatory standards for cyprinid fisheries. For example, Carpenters Road, in the lower Lee, failed to meet the standards for dissolved oxygen and ammonia. Also river and canal fisheries are vulnerable to run-off pollution incidents, particularly during localised summer storm events. Between 1986 and 2001, 17 category 1 and 2 fish kills were recorded in the lower Lee catchment. Event-driven urban run-off or storm sewage discharging into the channel were recorded as the source of pollution for 11 of these events. Minimum dissolved oxygen levels recorded (at the time investigated) were between 3 and $33 \%$ saturation. The largely canalised nature of the habitat in these lower reaches is reflected in the absence of macroinvertebrate taxa favouring stony, fast-flowing or macrophyte habitats e.g. cased-caddis flies, blue-winged olive mayflies (Ephemerellidae) and black-flies (Simuliidae) found elsewhere in the catchment and a dominance of burrowing taxa and or those favouring slow-flowing muddy habitats, e.g. orb mussels (Sphaeriidae), river-snails (Viviparidae), swan-mussels (Unionidae) and the water hog-louse (Asellidae). The Chinese mitten crab (a non-native species) has been recorded in the lower Lee (and the Thames). When the species is abundant, its burrowing activities can cause bank erosion..

Fish surveys on the River Lee and Navigation found the piscivorous perch (Perca fluviatilis) and pike (Esox lucius) also insectivorous and roach (Rutilus rutilus) a benthic feeder tolerant of eutrophic waters, to dominate the freshwater length of the Lee Navigation and associated channels. The lower reaches of the Lee were dominated by bream (Albramis brama) and tench (Tinca tinca), both benthic feeders typical of slow flowing or overgrown large rivers or backwaters. Higher fish biomass within the Lee Navigation side-loops and tributaries generally reflected the increased habitat diversity of these stretches. The low variability in channel profile and habitat diversity of the Lee Navigation is deemed to have limited its fish communities. In addition to eels, 'marine' species mullet (Liza ramada), flounder (Platichthys flesus) and smelt (Osmerus eperlanus) dominated the catch within the tidal lower Lee downstream of Stratford Marsh; this reach is an important nursery for these fish species. The spread of nonnative species, such as the piscivorous zander (Stizostedion lucioperca) found in and downstream of Stanborough Lakes, may have a negative effect on the native fisheries in the Lee.

Endocrine disruptors are known to cause hormonal changes in fish; in the River Lee these have led to up to $57 \%$ of male roach containing both male and female characteristics. The occurrences of these characteristics are closely correlated with the relative proportion of STW effluent in the river (Environment Agency, 2001a).

\section{Conclusions}

This is the first study to investigate the links between water quality and aquatic ecology in a major UK river system affected by agriculture and dense urbanisation. The study contrasts with research into more upland or rural areas, such as those included in the LOIS and LOCAR programmes. Geographically, the highly populated urbanised reaches of the Lee in both the upper and lower catchment exhibit the highest levels of nutrient enrichment and sewage pollution, as illustrated by both chemical and biological determinands. Additionally, the lower Lee has raised levels of both metals and organic substances. This, when combined with flow regulation and canalisation of the channel, has led to impoverished aquatic fauna, tolerant of both nutrient enrichment and low habitat diversity. Bioaccumulation within the food chain could potentially cause enduring problems both within and beyond the confines of the watercourse. The microbiological water quality of these 
lower reaches has implications for the present and planned recreational uses of the watercourse. By contrast, within the mid-catchment reaches and upper agricultural tributaries less nutrient enrichment and channel alteration has permitted a more diverse aquatic fauna.

Major STWs were the principal point source inputs of nutrients, metals and organic determinands to the catchment. Highest concentrations were from either large or small STWs, depending on determinand (for example, high concentrations of copper, nickel and zinc were notably associated with large STWs and high BOD and low oxygen saturation with small works). Detrimental effects on the receiving watercourses were evident (i.e. detectable increases in nutrients, depressed oxygen levels concurrent with reduced biotic scores). Diffuse inputs of nutrients largely from agricultural runoff but also from the smaller sewage works are evident in the tributaries in the north-east of the catchment.

Water quality issues within the Lee catchment have implications for water resource management, itself a confounding factor in determining this water quality. Poor habitat diversity within substantial sections of the catchment has further restricted aquatic faunal communities. Present and potential uses of the river and tributaries will, therefore, be limited by these factors.

\section{Acknowledgements}

The authors acknowledge the help of the Environment Agency and British Waterways for making all the data available. London's Waterway Partnership provided financial support for the review.

\section{References}

Anon, 1999. S-PLUS 2000. Data Analysis Products Division. MathSoft, Inc.,Seattle, USA.

British Geological Survey, 1993. Sheet 256-North London (Solid and Drift). British Geological Survey, Nottingham, UK.

Centre for Ecology and Hydrology, 2000, Hydrometric Register and Statistics, Wallingford, UK. 207pp.

Environment Agency, 1992, Lower River Lee Survey 1991. Environment Agency, Hatfield, UK.

Environment Agency, 1994, River Lee Navigation Channel Fisheries Survey 1993. Environment Agency, Hatfield, UK.

Environment Agency, 1997. The Lee Fact File. Environment Agency, Bristol, UK.

Environment Agency, 2001a. Local Environment Agency Plan (LOCA) - Upper Lee. Environment Agency, Bristol, UK.

Environment Agency, 2001b. Local Environment Agency Plan (LOCA) - North London. Environment Agency, Bristol, UK.

Flavin, R.J. and Joseph, J.B., 1983. The hydrology of the Lee Valley and some effects of artificial recharge. Quart. J. Eng. Geol., 16, 65-82.
Flynn, N.J., Paddison, T and Whitehead, P.G., 2002. INCA Modelling of the Lee System: strategies for the reduction of nitrogen loads. Hydrol. Earth Syst. Sci., 6, 467-483.

Geological Survey of Great Britain, 1978. Sheet 239 - Hertford (Drift). Ordnance Survey, Southampton, UK.

Halcrow Water, 1999. Water and Environment Water Quality Strategy for the Lower River Lee. Halcrow Water, Crawley, UK. Heathwaite, A.L., Burt, T.P. and Trudgill, S.T., 1993. Overview the Nitrate Issue. In: Nitrate: Processes, Patterns and Management, T.P. Burt, A.L. Heathwaite and S.T. Trudgill (Eds.), Wiley, Chichester, UK. 3-22.

Langan, S.J., Wade, A.J., Smart, R.P., Edwards, A.C., Soulsby, C., Billett, M.F., Jarvie, H.P., Cresser, M.S., Owen, R. and Ferrier, R.C., 1997. The prediction and management of water quality in a relatively unpolluted major Scottish catchment: current issues and experimental approaches. Sci. Total Envir., 194/195, 419-435.

Maund, S.J., Taylor, E.J. and Pascoe, D., 1992. Population responses of the freshwater amphipod crustacean Gammarus pulex (L.) to copper. Freshwater Biol., 28, 29-36.

Neal, C., 1997. A view of water quality from the Plynlimon watershed (Special Issue). Hydrol. Earth Syst. Sci., 1, 743-753.

Neal, C. (Ed.), 1998. Water Quality and Biology of UK rivers entering the North Sea: The Land Ocean Interaction Study (LOIS) and associated research. Sci. Total Envir., 210/211.

Neal, C. and Robson, A.J., 2000. A summary of river water quality data collected within the Land Ocean Interaction Study: core data for Eastern UK rivers draining to the North Sea. Sci. Total Envir., 251/252, 587-668.

Neal, C., Skeffington, R., Neal, M., Wyatt, R., Turner, H. and Hewitt, E., 2004.Rainfall and runoff water quality of the Pang and Lambourn, tributaries of the River Thames, south eastern England. Hydrol. Earth Syst. Sci., 8, 601-613.

O'Shea, M.J. and Sage, R., 1999. Aquifer recharge: an operational drought-management strategy for north London. J. Chart. Inst. Water Environ. Manage., 13, 400-405.

Pilcher, M.W. and Copp, G.H., 1997. Winter distribution and habitat use by fish in a regulated lowland river system of south east England. Fisheries Manage. Ecol., 4, 199-215.

Reid, K., 1995. River Revival: Catchment Management Plan. Surveyor, 182, 20-21.

Robson, A.J., Neal, C., Currie, J.C., Virtue, W.A. and Ringrose, A., 1996. The water quality of the Tweed and its tributaries. Institute of Hydrology Report No. 128, Wallingford, UK. 58pp.

Royal Commission, 1992. Royal Commission on Environmental Pollution. Sixteenth Report. Freshwater Quality. HMSO, London, UK. 291pp.

Rust Environmental, 1995. NRA (Thames Region) Lower Lee Improvements - downstream of Tottenham. Rust Environmental, Hatfield, UK.

Snook, D.L., Whitehead, P.G. and McEvoy, J., 2002. A review of water quality of the River Lee. A report for London's Waterway Partnership. AERC, The University of Reading, Reading, UK.

Whitehead, P.G., Young, P.C. and Hornberger, G.E., 1979. A systems model of flow and water quality in the Bedford Ouse River system: Part I, Streamflow Modelling. Water Res., 13, $1115-1169$.

Whitehead, P.G., Beck, M.B. and O'Connell, P.E., 1981. A system model of flow and water quality in the Bedford Ouse River system: Part II, Water Quality Modelling. Water Res., 15, 11571171.

Whitehead, P.G. and Williams, R., 1984. Modelling nitrate and algal behaviour in the River Thames. Water Sci. Technol., 16, 621-633.

Wright, J.F., Sutcliffe, D.W. and Furse, M.T., 2000. Assessing the biological quality of fresh waters. RIVPACS and other techniques. Freshwater Biological Assocation, Cumbria, UK. 